\title{
LONG-TERM EVALUATION OF THE FUNCTIONAL AND ESTHETICAL OUTCOMES FOR THE NEW METHOD OF THE TOE-TO-HAND TRANSFER FOR FULL-LENGTH THUMB RECONSTRUCTION IN CONGENITAL THUMB'S HYPOPLASIA IN CHILDREN
}

\author{
Dzintars Ozols ${ }^{1,2, \#}$, Jānis Zariņš ${ }^{1,2}$, and Aigars Pētersons ${ }^{1}$ \\ ${ }^{1}$ Rīga Stradiṇš University, 2 Hipokrāta Str., Rīga, LV-1038, LATVIA \\ ${ }^{2}$ Latvian Centre of Plastic, Reconstructive and Microsurgery, Rīga East University Hospital, 410 Brīvības Ave., Rīga, LV-1024, LATVIA \\ \# Corresponding author: dz.ozols@gmail.com
}

Contributed by Aigars Pētersons

\begin{abstract}
Congenital thumb hypoplasia is a rare deformity of the upper extremity. Incidence of thumb hypoplasia type I-V was 2-3 and type IIIb-V was 0.5-1 per 20000 newborns per year in Latvia. The classification of thumb hypoplasia was created by Blauth in 1967 (type I to V). The base of the metacarpal bone is absent for hypoplasia type IIIb-V; therefore, toe-to hand transplantation is not recommended. A stable first carpometacarpal joint has been considered a mandatory factor for successful toe-to-hand transplantation. A technique for toe-to-hand transplantation for thumb hypoplasia type IIIb-V patients has been described in literature but overall results were not better than pollicisation. The aim of this study is to describe a new technique for thumb reconstruction with a second toe transfer with metatarsophalangeal joint arthrodesis, which can provide a 5-digit hand and restore the functionality of the thumb for thumb hypoplasia IIIb-V. Long-term follow up was done to evaluate the functions and aesthetics of the hands. A survey to evaluate aesthetical outcome for the transplantation method and pollicisation method was completed by 290 respondents. The overall population rated the aesthetic outcomes of the new transplantation method significantly higher than for pollicisation $(p<0.0001)$.
\end{abstract}

Key words: congenital thumb hypoplasia, toe-to-hand transfer, thumb reconstruction, joint arthrodesis.

\section{INTRODUCTION}

Congenital anomalies are rare, affecting $1-2 \%$ of newborns and only $10 \%$ of them have upper limb anomalies (Riley and Burgess, 2009). In Latvia thumb hypoplasia represents with an incidence of 2-3 per 20000 newborns per year. The classification system created by Blauth in 1967 (type I to V), modified by Manske and McCarroll in 1992 (adding type IIIa, IIIb), and recently improved by Tonkin (adding type $2 a, 2 b, 2 c$ ) has been used to stratify the extent of the structural deficiencies for the hypoplastic thumbs (Chow et al. 2012; Trist et al., 2015). The type-III thumb is short and unstable, with partial absence of the first metacarpal, hypoplasia or absence of the extrinsic extensor and flexor tendons, aplasia of the thenar muscles, instability of the carpometacarpal joint, and adduction contracture of the first ray to a complete absence of first digit and its components in type IV and V (Shibata et al., 1998). The goal of treatment is ultimately to provide the child with a stable and functional thumb unit (Riley and Burgess, 2009). Pollicisation (transposition of the second finger to thumb's position) is a method of choice for type III, IV, and V hypoplasia (Staines et al., 2005; Lightdale-Miric et al., 2015). Nevertheless, in cases with specific cultural or social background, where a 5-digit hand is crucial, toe-to-hand transplantation is preferred (Shibata et al., 1998; Tonkin, 2011; Soldato et al., 2014).

A new surgical technique was developed in the Microsurgery Centre of Latvia and used by authors since 2010. A second toe-to-thumb transfer with metatarsophalangeal joint arthrodesis (chondrodesis) is done to improve the length 
and stability of neo metacarpal. The proximal interphalangeal joint (PIPJ) becomes a metacarpophalangeal joint (MCPJ) and the distal interphalangeal joint (DIPJ) becomes an interphalangeal joint (IPJ). Also, a "pseudo" first carpometacarpal joint (CMCJ) develops between the carpal bones and base of the metatarsal. The aim of this study is to describe the new technique for thumb reconstruction with a second toe transfer with metatarsophalangeal joint arthrodesis, which can provide a 5-digit hand and restore the functionality of the thumb for thumb hypoplasia IIIb-V. Longterm follow up was undertaken to evaluate the functions and aesthetics of the hands.

\section{MATERIALS AND METHODS}

A total of two patients with thumb hypoplasia type IIIb had operations using the new toe-to-hand transplantation method. Both patients underwent long-term follow-up evaluation. A visual analogue scale (VAS) was used for aesthetic evaluation (Table 1). Patients and their parents were asked to give a score from 1 to 10 points (more is better) to two questions: "Does the transplanted toe look like a thumb?" and "Does the transplanted toe work like a thumb?". Prior to the toe transplantation three patients with type $\mathrm{V}$ and 1 patient with type IV thumb hypoplasia underwent the pollicisation procedure. Their post-operative aesthetic outcome was compared to the toe-to-hand transplantation using the VAS. To establish functionality patients were asked to complete the Disabilities of the Arm, Shoulder and Hand (DASH) survey. The range of motion (ROM) in three joints of the thumb was measured using a hand goniometer, the strength of the grasp and pinch grip were measured using a Jamar dynamometer, and the two-point discrimination test was performed. To determine the overall population's perspective on aesthetic outcomes between a 4-digit hand after the pollicisation and a 5-digit hand with a transplanted thumb, an internet survey was created. Responders were asked to give a VAS from 1 to 10 (more is better) points and to vote for better aesthetic outcome between toe transplantation, including donor-site, and pollicisation. Statistical evaluation was performed using the IBM SPSS Statistics v.22 (Statistical Package for the Social Sciences) Student's t-test and Wilcoxon-Mann-Whitney test.

Table 1

COMPARISON OF THE AESTHETIC OUTCOMES BETWEEN THE POLLICISATION AND THE NEW TOE-TO-HAND TRANSPLANTATION METHOD

\begin{tabular}{c|c|c|c}
\hline Technique & $\begin{array}{c}\text { Patients' mean } \\
\text { VAS aesthetical } \\
\text { score }\end{array}$ & $\begin{array}{c}\text { Survey's } \\
\text { responders' mean } \\
\text { VAS aesthetical } \\
\text { score }\end{array}$ & $\begin{array}{c}\text { "This technique } \\
\text { has better } \\
\text { aesthetic } \\
\text { outcomes." } \\
\text { (total n of } \\
\text { responders) }\end{array}$ \\
\hline Pollicisation & $\begin{array}{c}4 \\
\text { (4 patients) } \\
9\end{array}$ & 5.84 & 35 \\
Transplantation & $\begin{array}{c}\text { (2 patients) } \\
\text { (2) }\end{array}$
\end{tabular}

The first patient was a ten-year-old girl with bilateral thumb hypoplasia - left hand grade I, right hand type IIIb. No operations for the left hand were performed. The right thumb was unstable and required reconstruction, but the patient and parents refused the pollicisation. Their requirement was a 5-digit hand. A new surgical method was developed the second toe transplantation with metatarsophalangeal joint arthrodesis to restore a functional full-length thumb in a 5-digit hand. Follow-up evaluation was done five years after thumb transplantation. The DASH score was 8 . The VAS score for two questions - 1) Does the transplanted toe looks like a thumb? and 2) Does the transplanted toe work like a thumb? - were answered as ten points of ten. The grasp for left hand (healthy) was $28 \mathrm{~kg}$ and for right (reconstructed) hand $-30 \mathrm{~kg}$; the difference between reconstructed vs healthy hand was 1.07. Pinch force for left hand (healthy) was $5 \mathrm{~kg}$ and for right (reconstructed) $1 \mathrm{~kg}$, and the difference between reconstructed vs healthy was 0.2 . The strength measurements were good, and grasp force is even better in the operated hand. Active motion of the both thumbs were measured. ROM for the right (reconstructed) hand was CMCJ $20^{\circ}$; MCPJ $90^{\circ}$ and for IPJ $45^{\circ}$ and for the left (healthy) hand was CMCJ $20^{\circ}$; MCPJ $80^{\circ}$ and for IPJ $50^{\circ}$. The results of follow up five years after the procedure seemed very satisfactory as there was active motion, stable CMCJ and functionality in the newly created thumb (Figs. 1-2).

The second patient was a two-year-old girl with a left radial longitudinal deficiency (RLD) grade IV (Bayne and Klug) and thumb hypoplasia type IIIb. Bilateral second toe transfers to reconstruct radial longitudinal deficiency were performed as a two-step procedure. In the first stage, radial longitudinal deficiency was treated using second metatarsal joint transplantation at the age of two and a second stage for the thumb reconstruction second toe transplantation with MTPJ arthrodesis from the left foot was used to restore a functional thumb at the age of four (Ozols et al., 2018). Follow-up evaluation was done at the age of 84 months, three years after the thumb reconstruction. The DASH score was 10.7. The VAS score for the question: Does the transplanted toe look like a thumb? - was answered as ten

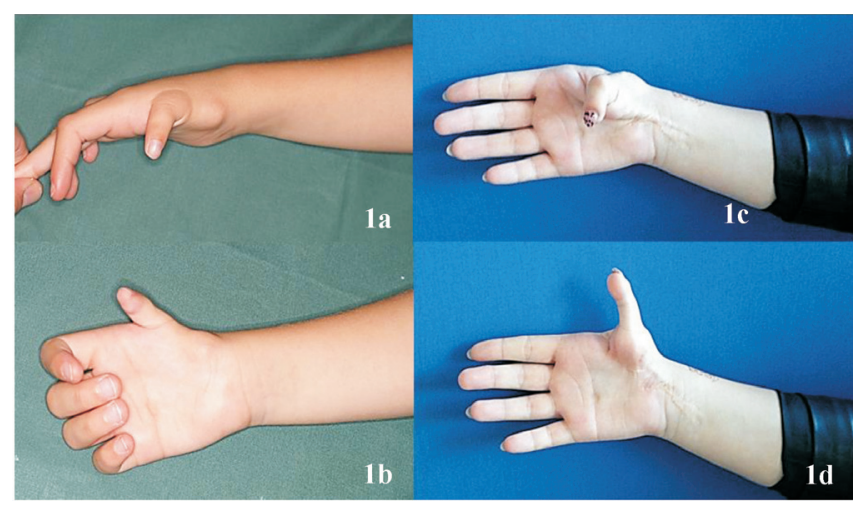

Fig. 1. Not stable, not functional thumb hypoplasia (1a-1b no flexion or extension possible). Functional outcome after toe to hand transplantation with MTPJ arthrodesis (5-year follow-up) (1c maximal flexion and 1d maximal extension). 


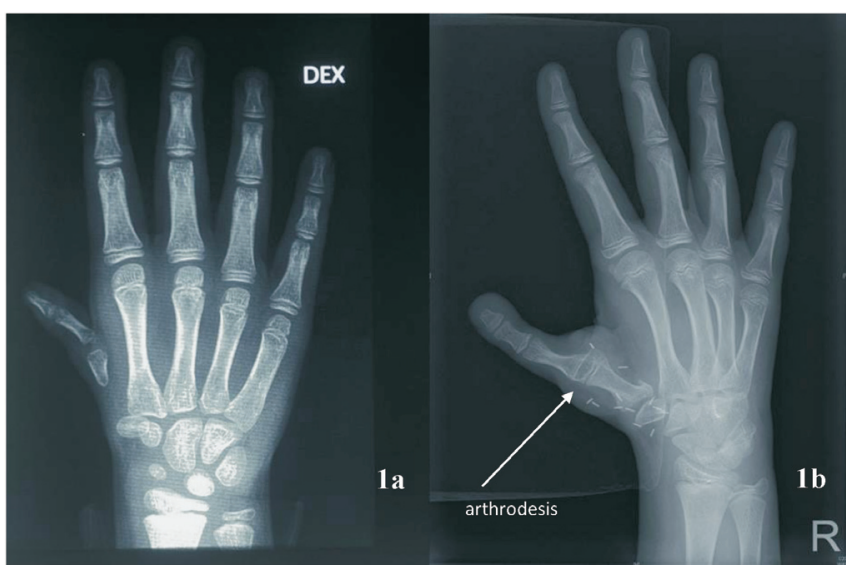

Fig. 2. X ray for thumb hypoplasia IIIb, no metacarpal base presented (1a). 5-year follow-up (1b) growth plates closed maximal metacarpal length achieved for $48 \mathrm{~mm}$. Stable neo trapeziometacarpal joint with possible movement for $20^{\circ}$. Place of arthrodesis of metatarsophalangeal joint marked with arrow.

points. The VAS score for the question - Does the transplanted toe works like thumb? - was answered as five out of the ten. Grasp for left hand (healthy) was $9 \mathrm{~kg}$ and for right (reconstructed) hand was $2 \mathrm{~kg}$; the difference between reconstructed hand vs healthy was 0.22 . Pinch force for the left hand (healthy) was $3 \mathrm{~kg}$ and for the right (reconstructed) was $0.5 \mathrm{~kg}$, with difference between reconstructed vs healthy -0.17 . The strength measurements were poor, as would be expected, but the patient was able to pinch and grasp to hold small and big objects, and she used her hand in the everyday activities. Active motion of the both thumbs was measured. ROM for the right (reconstructed) hand was CMCJ $15^{\circ}$; MCPJ $90^{\circ}$ and for IPJ $10^{\circ}$ and for left (healthy) hand was CMCJ $20^{\circ}$; MCPJ $60^{\circ}$ and for IPJ $60^{\circ}$. Active motion of the thumb and wrist joint was possible for reconstructed radial longitudinal deficiency. The MTPJ transfer provided stability and functionality for the wrist. There was stability in the CMCJ, which allowed a stable grasp.

Surgical technique. The second toe is usually selected for thumb reconstruction because of its constant and well described vascular anatomy. The second toe consists of 3 joints - MTPJ, PIPJ, and DIPJ. To reconstruct a thumb only two joints are required - MCPJ and IPJ. MTPJ is anatomically similar to MCPJ, but with one major difference - MTPJ is limited to flexion. The MCPJ range of motion is of $30-0-90^{\circ}$, but for MTPJ $-80-0-30^{\circ}$; therefore, the MTPJ is very difficult to use for thumb reconstruction and in our operations we made an arthrodesis to obtain a long and stable thumb. There was no additional fixation or ligament reconstruction of the CMCJ. Metatarsal bone can be fixated on a trapezium or in a place that looks acceptable for the new thumb.

Flexor and extensor tendon reconstructions are very important to predict a good functional outcome. In our operations, extensor indicis proprius (EIP) was used for extensor pollicis longus (EPL), and second interosseous muscles, if available, were used for abductor and palmaris longus (PL) for flexor pollicis longus (FPL).
Ethics approval was received before the study, in 2014, from the Riga East Eniversity Hospital Ethical Committee.

\section{RESULTS}

The parents were very satisfied with both aesthetic outcomes and functionality of the thumb created using the new toe-to hand transplantation method. The combined VAS score for aesthetic and functionality answered by families of both patients who underwent the toe-to hand transplantation were rated on average with 8.55 (5-10) points (Fig. 3). The VAS score given by the first patient was ten points for aesthetical appearance of the thumb and functionality was rated as eight points of ten. The second patient gave also ten points for aesthetics and five points for functionality. The parents were less satisfied because of the deformity after radial club hand reconstruction. Patients gave scores of 8.0 and 10.7 points in the DASH survey with an average DASH score as 9.35 points. Grasp and pinch was possible with a stable CMCJ. Both evaluated patients had a stable thumb with possible movements in CMCJ, MCPJ, and IPJ that ensured good grasp and pinch. Both patients used their hands in daily life. No donor side complains were observed. Families of patients who had underwent pollicisation procedure gave and average VAS of 6.7 (5-8) points and the DASH score was 19.8 (6-26.7).

Long-term functional and aesthetical evaluation results for patients who underwent reconstruction using the new toe-to hand method or classical pollicisation method could not be statistically evaluated as the patient groups were too small. To compare aesthetical results for the new toe-to hand transplantation method and classical pollicisation method, a public survey was used. The survey was completed by 290 respondents. Social media platforms such as Facebook and WhatsApp were used for distribution. Most of the respondents were female (195 respondents), aged between 19 and

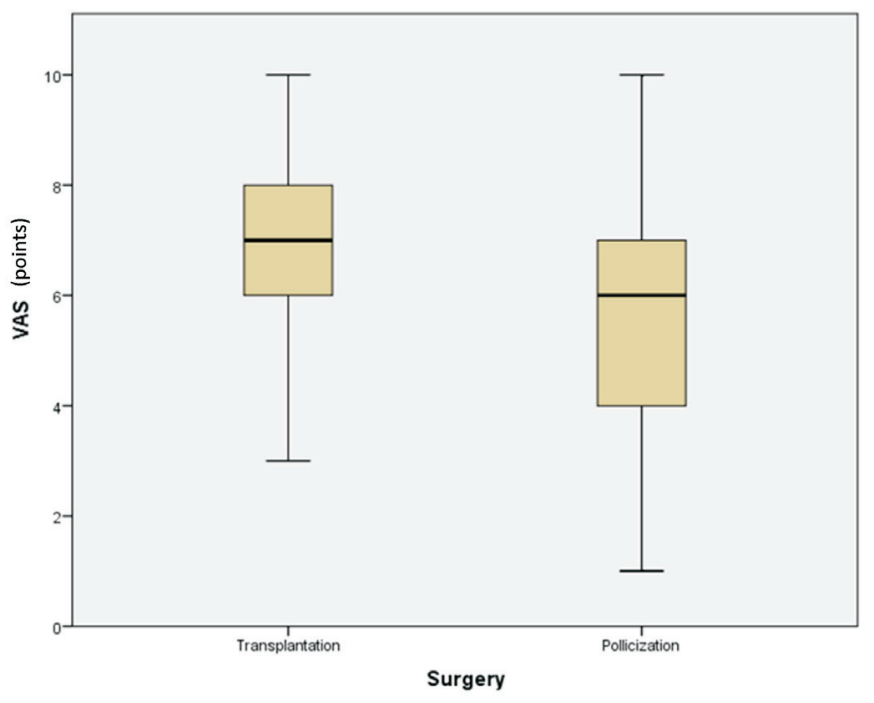

Fig. 3. Results of toe-to-hand transplantation and pollicisation aesthetic outcomes by visual analogue scale (VAS) survey. The new transplantation method was evaluated higher with an average of seven points than that for pollicisation (average of six points). 
30 years (185 respondents). VAS for the toe transplantation was $7.04(3-10)$, whereas for the pollicisation -5.84 (1-10) (Table 1). The scores significantly differed $(p<$ $0.0001)$. VAS for the toe donor site was $7.41(1-10)$. For the question" Which technique has better aesthetic outcomes?" 213 respondents answered "transplantation", 35 respondents selected pollicisation and 42 respondents considered both options to have equally good results.

\section{DISCUSSION}

The congenital thumb hypoplasia represents with lack of functions and significantly affects quality of life in development of the afflicted child. Therefore, every case of hypoplastic thumb must be evaluated, all potential risks identified, and a proper plan of reconstruction applied. Despite the development of the classification systems and clarifications of each type, there is still ongoing discussion on which method is superior to others. Overall generalisation cannot be applied to all patients. There are different methods with various functional outcomes for the hypoplastic thumb reconstructions described in the literature. These are pollicisation (Buck-Gramcko 1971), metacarpal lengthening, hemimetatarsal transfer (Chow et al., 2012), free joint (Foucher et al., 2001) and toe-to-hand transplantation (Tu et al., 2004; Jones and Kaplan, 2013).

The concept of the surgery is directed towards the addition or removal of tissue, correction of deformity and stabilisation of joints to maintain their mobility. The carpometacarpal joint is perhaps the major determinant of effective thumb mobility, and is less important at metacarpophalangeal and interphalangeal joints to preserve stability (Tonkin, 2011). Several authors prefer pollicisation as the first choice for hypoplastic thumb reconstruction, as it provides optimal thumb function and satisfactory results (Riley and Burgess, 2009; Light and Gaffey, 2010; Tonkin, 2011). Others have reported that pollicisation results in poor strength, cosmetics and overall function, and normal dexterity is achieved using more altered control strategies (Lightdale-Miric et al., 2015). Pollicisation can be very controversial also in cases of type III and IV, where a 5-digit hand is transformed into a 4-digit hand. It is also very crucial in societies with a specific cultural or social background.

In type III and IV hypoplasia, the carpometacarpal joint can be reconstructed through the transfer of both vascularised and non-vascularised metatarsophalangeal joints (Foucher et al., 2001). Shibata et al. (1998) suggests that an unstable hypoplastic IIIb thumb can be reconstructed with a free vascularised metatarsophalangeal joint transfer and adequate motions can be achieved with tendon transfers. Another option is to transfer the reverse non-vascularised distal twothirds of the fourth metatarsal bone, reported (Tan and Tu, 2013) on a series of patients undergoing free second toemetatarsal bone transfer for reconstructing type IIIb and IV thumbs. However, the results often reported a less functional hand compared with index finger pollicisation (Tan and $\mathrm{Tu}, 2013)$.
There are only a few studies that suggest microsurgical toeto-hand transfers for type III and IV hypoplasia, due to technical difficulties and donor site morbidity (Tu et al., 2004; Ozols et al., 2018). The main aim of the new technique for thumb reconstruction with second toe transplantation and MTPJ arthrodesis (chondrodesis) was salvage of a 5-digit hand and restoration of the functionality of the thumb. Evidently, this method can be an alternative for pollicisation in reconstruction of thumb hypoplasia type IIIb-V. We consider that MTPJ arthrodesis is an answer for stability and length of the thumb. There are no doubts about the CMCJ stability without ligament reconstruction, and it appears that paediatric patients can make stable pseudo joints. A stable thumb can be achieved even without trapezium bone. The second toe transplantation is very difficult for young patients, but it is possible to achieve good functionality and good donor side cosmetics. We performed the second MTPJ transplantation for radial club hand deformity as suggested previously (Vilkki, 2008) and conducted another toe transplantation for thumb reconstruction in two separate operations. The results for 5-digit hand reconstruction in radial club hand patients is very difficult to predict, but in our case, the results were satisfactory (Ozols et al., 2018).

The width of the hand is maintained, which assists grip. However, the problems are many: scarring is significant, the "new" thumb remains small and may require lengthening, joints are often unstable, requiring fusion subsequently, and mobility is poor (Tonkin, 2011). Toe transplantation for thumb hypoplasia patients was performed by Tu in 2004 (Tu et al., 2004). The main differences with our technique was in the first CMCJ arthrodesis and MCPJ enforcement by ligament repair, where in our cases the CMCJ was developed as a stable and functioning joint and arthrodesis was done in the MTPJ and no ligament repairs and intrinsic rebalancing needed. A stable and long first metacarpal bone created using MTPJ arthrodesis is an option provided by our technique. Then the PIPJ and DIPJ of transplanted toe becomes IPJ and MCPJ of the new thumb, which works similar as in the pollicisation technique. The time of the procedure was expanding up to even 12 hours, which is three times longer than in our experience. Previously reported problems have been significantly reduced ROM and difficulties providing a strong grip (Tu et al., 2004; Tan and $\mathrm{Tu}, 2013)$. Congenital hand deformities are rare and it is difficult to collect a wide series of treated patients. Results for aesthetical appearance of the thumb rated by families of the patients gave a VAS score of $8.75(5-10)$ for the new method and $6.25(2-8)$ for the classical pollicisation method. The public survey for the new to-to hand transplantation method resulted in a slightly higher VAS score (7.04, $3-10$ ), which was not surprising as families of patients can evaluate problematic hands better. The public survey results showed that the new toe-to-hand transplantation procedure was evaluated significantly higher $(p<0.0001)$. The aesthetical results and functional results as DASH score were 9.35 (8-10.7) points for the new method and 19.8 (6-26.7) for the pollicisation method indicating the toe-tohand transplantation using the new method was successful. 


\section{CONCLUSION}

Thumb hypoplasia is a rare congenital deformity of the hand. Thumb hypoplasia IIIb (Blauth) can be expected every two years in Latvia. We are able to present a new second toe-to-hand transplantation with metatarsophalangeal joint arthrodesis method with good functional and aesthetical results. Long-term functional and aesthetical results for the new surgical method were better than the functional results for the pollicisation method. The DASH score 9.35 points for the toe-to-hand transplantation and 19.8 points for pollicisation. Aesthetical results (VAS score) for the new toe-to-hand transplantation method was 8.55 and for the pollicisation - 6.7. A public survey with 290 responders showed significantly higher scores for aesthetical results for the functional thumb in the five digit hand created by the new toe-to hand transplantation method, in comparison of the four digit hand created by pollicisation.

We are able to present good functional and aesthetical outcome for our new toe-to-hand transplantation method. These are preliminary results for our newly created toe-tohand method but this method can provide a stable, functional and aesthetic thumb in a five digit hand. The aesthetical survey clearly showed that responders prefer a functional five digit hand created by the new toe-to hand method instead a four digit hand provided by the classical pollicisation method.

\section{CONFLICT OF INTERESTS}

The authors declared no potential conflicts of interest with respect to the research, authorship, and/or publication of this article.

\section{REFERENCES}

Buck-Gramcko, D. (1971). Pollicization of the index finger. J. Bone Joint Surg., 53 (8), 1605-1617.

Chow, C., Ho, P., Tse, W., Hung, L. (2012). Reconstruction of hypoplastic thumb using hemi-longitudinal metatarsal transfer. J. Hand Surgery (European Volume), 37 (8), 738-744.

Chow, C. S., Ho, P. C., Tse, W. L., Hung, L. K. (2012). Reconstruction of hypoplastic thumb using hemi-longitudinal metatarsal transfer. J. Hand Surg. Eur., 37 (8), 738-744.

Foucher, G., Medina, J., Navarro, R. (2001). Microsurgical reconstruction of the hypoplastic thumb, type IIIB. J. Reconstr. Microsurg., 17 (01), 009-016.
Foucher, G., Medina, J., Navarro, R. (2001). Microsurgical reconstruction of the hypoplastic thumb, type IIIB. J. Reconstr. Microsurg., 17 (1), 9-15.

Jones, N. F., Hansen, S. L., Bates, S. J. (2007). Toe-to-hand transfers for congenital anomalies of the hand. Hand Clinics, 23 (1), 129-136.

Jones, N. F., Kaplan, J. (2013). Indications for microsurgical reconstruction of congenital hand anomalies by toe-to-hand transfers. Hand, 8 (4), 367-374.

Light, T. R., Gaffey, J. L. (2010). Reconstruction of the hypoplastic thumb. J. Hand Surg. Amer., 35 (3), 474-479.

Lightdale-Miric, N., Mueske, N. M., Lawrence, E. L., Loiselle, J., Berggren, J., Dayanidhi, S., Stevanovic, M., Valero-Cuevas, F. J., Wren, T. A. L. (2015). Long term functional outcomes after early childhood pollicization. J. Hand Ther., 28 (2), 158-166.

Ozols, D., Zarins, J., Petersons, A. (2018). Bilateral second toe transfers to reconstruct radial longitudinal deficiency: A case report. J. Hand Surg. Eur., 43 (10), 1114-1116.

Riley, S. A., Burgess, R. C. (2009). Thumb hypoplasia. J. Hand Surg. Amer., 34 (8), 1564-1573.

Shibata, M., Yoshizu, T., Seki, T., Goto, M., Saito, H., Tajima, T. (1998). Reconstruction of a congenital hypoplastic thumb with use of a free vascularized metatarsophalangeal joint. J. Bone Joint Surg. Amer., 80 (10), 1469-1476.

Soldato, F., Zlotolow, D. A., Kozin, S. H. (2014). Thumb hypoplasia. J. Hand Surg., 38 (7), 1435-1444.

Staines, K. G., Majzoub, R., Thornby, J., Netscher, D. T. (2005). Functional outcome for children with thumb aplasia undergoing pollicization. Plast Reconstr. Surg., 116 (5), 1314-1323; discussion 1324-1315.

Tan, J., Tum Y.-K. (2013). Comparative study of outcomes between pollicization and microsurgical second toe-metatarsal bone transfer for congenital radial deficiency with hypoplastic thumb. J. Reconstr. Microsurg., 29 (9), 587-592.

Tonkin, M. (2011). Surgical reconstruction of congenital thumb hypoplasia. Indian J. Plast. Surg., 44 (2), 253-265.

Trist, N. D., Tonkin, M. A., van der Spuy, D. J., Yoon, A., Singh, H. P., Lawson, R. D. (2015). Stability of the basal joints of the new thumb after pollicization for thumb hypoplasia. J. Hand Surg. Amer., 40 (7), 1318-1326.

Tu, Y.-K., Yeh, W.-L., Sananpanich, K., Ueng, S. W.-N., Chou, Y.-C., Ma, C.-H., Lee, Z.-L. (2004). Microsurgical second toe-metatarsal bone transfer for reconstructing congenital radial deficiency with hypoplastic thumb. J. Reconstr. Microsurg., 20 (03), 215-225.

Tu, Y. K., Yeh, W. L., Sananpanich, K., Ueng, S. W., Chou, Y. C., Ma, C. H., Lee, Z. L. (2004). Microsurgical second toe-metatarsal bone transfer for reconstructing congenital radial deficiency with hypoplastic thumb. $J$. Reconstr. Microsurg., 20 (3), 215-225.

Vilkki, S. K. (2008). Vascularized metatarsophalangeal joint transfer for radial hypoplasia. Semin. Plast. Surg., 22 (3), 195-212. 
KĀJAS OTRĀ PIRKSTA JAUNĀS TRANSPLANTĀCIJAS METODES PILNA GARUMA ĪKŠKA REKONSTRUKCIJAI ILGTERMIN̦A ESTĒTISKO UN FUNKCIONĀLO REZULTĀTU NOVĒRTĒ ̌̌ANA IEDZIMTU PLAUKSTAS DEFORMĀCIJU PIRMĀ PIRKSTA HIPOPLĀZIJU ĀRSTĒ̄̌SANĀ BĒRNIEM

Iedzimtas pirmā pirksta hipoplāzijas ir reti sastopamas augšējās ekstremitātes deformācijas. Latvijā pirmā pirksta I-V pakāpes hipoplāziju incidence bija 2-3 un IIIb-V - 0,5-1 uz 20000 jaundzimušajiem gada laikā. Iedzimtu pirmā pirksta hipoplāziju klasifikāciju izveidoja Blauss (Blauth) 1967. gadā, tās iedalot pakāpēs no I līdz V. Pirmā metakarpāāā kaula bāze ir neattīstīta pirmā pirksta hipoplāziju pacientiem, sākot ar IIIb pakāpi, līdz ar to kājas pirksta transplantācija netiek rekomendēta. Stabila pirmā karpometakarpālā locītava ir nepieciešama, lai varētu veikt funkcionālu kājas pirksta transplantāciju. Literatūrā publicēta kājas pirksta transplantācijas metode iedzimtas pirmā pirksta hipoplāzijas IIIb-V pacientu ārstēšanai, bet iegūtie rezultāti nebija labāki kā klasiskās pollicizācijas metodes rezultāti. Šì pētījuma mērḳis ir aprakstīt kājas otrā pirksta ar metatarsofalangeālās locītavas artrodēzi jaunās transplantācijas metodes rezultātus, kas nodrošina piecu pirkstu plaukstas izveidi pacientiem ar iedzimtu pirmā pirksta hipoplāziju IIIb-V pakāpē. Tika veikta ilgtermiņa funkcionālo un estētisko plaukstas rezultātu novērtēšana bērniem pēc kājas otrā pirksta transplantācijas ar metatrsofalangeālās locìtavas artodēzi. Aptaujas anketas, kuras aizpildīja 290 respondenti, tika izmantotas, lai salīdzinātu pollicizācijas un jaunās transplantācijas metodes estētiskos rezultātus. Jaunās transplantācijas metodes estētiskie rezultāti tika novērtēti labāk nekā klasiskās pollicizācijas metodes estētiskie rezultāti (statistiskā ticamība $p>0,0001$ ). 